Hydrol. Earth Syst. Sci., 14, 301-307, 2010

www.hydrol-earth-syst-sci.net/14/301/2010/

(C) Author(s) 2010. This work is distributed under

the Creative Commons Attribution 3.0 License.

\title{
Forest decline caused by high soil water conditions in a permafrost region
}

\author{
H. Iwasaki ${ }^{1}$, H. Saito ${ }^{1}$, K. Kuwao ${ }^{1}$, T. C. Maximov ${ }^{2}$, and S. Hasegawa ${ }^{1}$ \\ ${ }^{1}$ Graduate School of Agriculture, Hokkaido University. North 9, West 9, Kita-ku, Sapporo, 060-8589, Japan \\ ${ }^{2}$ Institute for Biological Problems of Cryolithozone, Siberian Division of Russian Academy of Sciences, 41, Lenin ave. \\ Yakutsk, 678891, Russia
}

Received: 28 August 2009 - Published in Hydrol. Earth Syst. Sci. Discuss.: 23 September 2009

Revised: 4 February 2010 - Accepted: 8 February 2010 - Published: 15 February 2010

\begin{abstract}
In the permafrost region near Yakutsk, eastern Siberia, Russia, annual precipitation (June-May) in 20052006 and 2006-2007 exceeded the 26-year (1982-2008) mean of $222 \pm 68 \mathrm{~mm}$ by $185 \mathrm{~mm}$ and $128 \mathrm{~mm}$, respectively, whereas in 2007-2008 the excedent was only $48 \mathrm{~mm}$, well within the range of variability. Yellowing and browning of larch (Larix cajanderi Mayr.) trees occurred in an undisturbed forest near Yakutsk in the 2007 summer growing season. Soil water content at a depth of $0.20 \mathrm{~m}$ was measured along a roughly $400 \mathrm{~m}$ long line transect running through areas of yellowing and browning larch trees (YBL) and of normal larch trees (NL). In the two years of supranormal precipitation, soil water content was very high compared to values recorded for the same area in previous studies. For both wet years, the mean degree of saturation $(s)$ was significantly greater in YBL than NL areas, whereas the converse was the case for the gas diffusivity in soil. This implies that rather than mitigating water stress suffered during normal precipitation years, elevated soil water conditions adversely affected the growth of larch trees. Eastern Siberia's taiga forest extends widely into the permafrost region. Was such supranormal annual precipitation to extend for more than two years, as might be expected under impending global climate changes, forest recovery may not be expected and emission of greenhouse gas might continue in future.
\end{abstract}

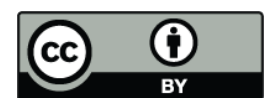

Correspondence to: $\mathrm{H}$. Iwasaki (iwasaki@env.agr.hokudai.ac.jp)

\section{Introduction}

Boreal forest ecosystems occupy $17 \%$ of the earth's terrestrial area and in storing over $30 \%$ of terrestrial carbon (Kasischke, 2000) greatly contribute to the global carbon cycle. Russia's boreal forests, largely consisting of extensive coniferous or "taiga" forests located in Siberia, cover an expanse of $8.51 \times 10^{6} \mathrm{~km}^{2}$, representing about $70 \%$ of the world's boreal forests (Kasischke, 2000; Food and Agriculture Organization, 2001). These Siberian forests extend widely over zones of continuous permafrost (Brown et al., 1997). Recently severe forest disturbances have been reported in Siberia caused by recent forest fires (Conard et al., 2002; Isaev et al., 2002) and deforestation (Shvidenko and Nilsson, 1996) in Siberia have severely disturbed forest ecosystems. Though occasional naturally-occurring forest fires are important in natural forest regeneration, a remarkable shortening of forest fire intervals has occurred in Siberia in recent years (Takahashi et al., 2002). Furthermore, these forest fires, representing an important source of $\mathrm{CO}_{2}$ which contributes to global warming, may have disturbed much wider expanses of forest than had previously been estimated (Soja et al., 2004).

Eastern Siberia's taiga forest is established on permafrost whose shallow (1-2 $\mathrm{m})$ active layer undergoes seasonal freeze-thaw cycles (Sugimoto et al., 2003). Due to the small amount of precipitation under the region's continental climate, water stress is a major limiting factor to tree growth (Nikolaev et al., 2009). However, in the last three years annual precipitation in Yakutsk, eastern Siberia has exceeded the 26-year (1982-2008) mean by 185, 128 and $48 \mathrm{~mm}$. Higher amounts of precipitation must mitigate the water stress of the trees and decrease the number of forest

Published by Copernicus Publications on behalf of the European Geosciences Union. 
(a)

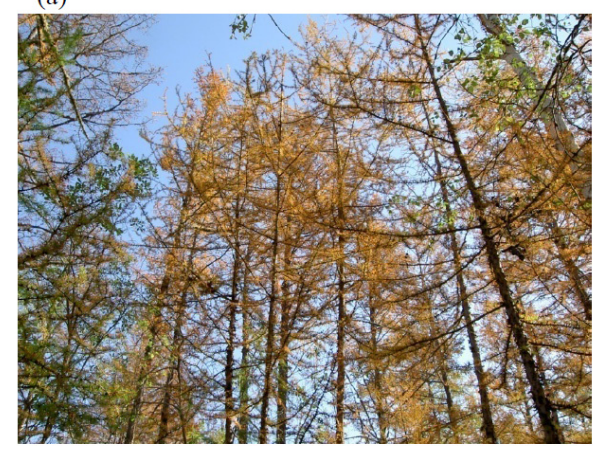

(b)

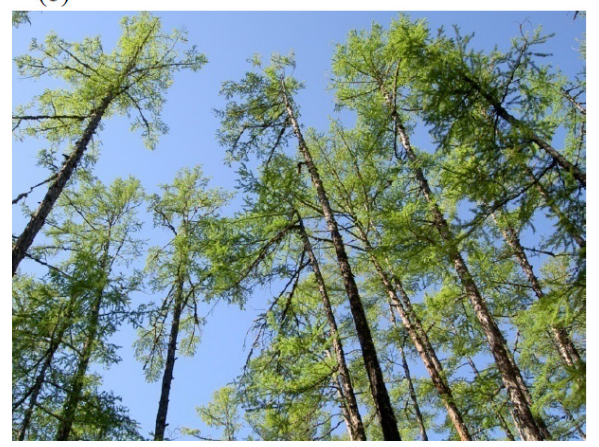

Fig. 1. Larch trees at the areas of yellowing and browning larch trees (YBL) (a) and normal larch trees (NL) (b) in 2007.

fires, which is considered to be beneficial to the carbon cycle. However in summer of 2007, even though in the growing season, yellowing and browning leaves of larch trees were recognized in an undisturbed forest near Yakutsk city and these larch trees withered in 2008. Senescence of the trees also emits $\mathrm{CO}_{2}$ to atmosphere in the process of decomposition (Epron et al., 1999). Such harmful effects of higher-thanaverage precipitation have not been reported in taiga forest. We investigated the distribution of senescent larch trees and completed a topo-sequence along a $400 \mathrm{~m}$ line transect to evaluate the relationship between larch senescence and soil water conditions using degree of saturation and relative gas diffusivity of the soils as representative parameters.

\section{Materials and methods}

\subsection{Site description}

This study was conducted at the Spasskaya Pad experimental forest $\left(62^{\circ} 15^{\prime} \mathrm{N}, 129^{\circ} 37^{\prime} \mathrm{E}\right)$ of the Institute for Biological Problems of the Cryolithozone, Yakutsk, Republic of Sakha, Russian Federation. The elevation is roughly $220 \mathrm{~m}$ a.s.l. The mean annual temperature and precipitation in this region are $-10^{\circ} \mathrm{C}$ and $213 \mathrm{~mm}$ (Archiborld, 1995), respectively. The forest, dominated by larch (Larix cajanderi Mayr.), with cowberry (Vaccinium vitis-idaea L.) in the understory, extends over the gently undulating eastern terrace of the Lena River. Growing at a density of $1000 \mathrm{ha}^{-1}$ the larch trees were $13 \mathrm{~m}$ tall and 160 years old, on average (Lopez et al., 2007). Larch roots are shallow and mainly limited to a depth of $0.40 \mathrm{~m}$ (Kuwada et al., 2002). The region's typical Gelisols consists of several layers: an upper litter layer $(0.02-$ $0.03 \mathrm{~m}$ depth), followed by a humus layer of about $0.10 \mathrm{~m}$, and a mineral layer of sandy to loamy soil beneath. The active layer ranges in depth from $1.0 \mathrm{~m}$ to a maximum of $2.0 \mathrm{~m}$. Snow melt ends in early May and soil freezing begins in late September to early October. Larch trees begin to foliate in May and the leaves fall in September.

\subsection{Soil sampling and measurement of soil properties}

A roughly $400 \mathrm{~m}$ line transect across strips of yellowing and browning larch trees (YBL) and remaining normal larch trees (NL) was chosen in 2007 (Fig. 1). Elevation was measured at $5 \mathrm{~m}$ intervals along the transect. Undisturbed $100 \mathrm{~cm}^{3}$ $\left(20 \mathrm{~cm}^{2}\right.$ surface $\times 5.1 \mathrm{~cm}$ height $)$ core samples and disturbed soil samples were collected at $10 \mathrm{~m}$ intervals along the transect in both 2007 (8 August) and 2008 (17 July) from the mineral layer at a depth of $0.20 \mathrm{~m}$. After measuring the mass, core samples were placed into an empty plastic tank. Deaired water was added gradually into the tank to saturate the core samples. Volumetric water content at saturation $\left(\theta_{\mathrm{s}}\right)$ and volumetric water content at sampling $(\theta)$ were determined by oven drying samples at $105^{\circ} \mathrm{C}$ for $24 \mathrm{~h}$.

All soil samples were classified by touch into three soil textures: sand (S), loamy sand (LS) or sandy loam (SL) using disturbed soil samples. Soil water retention curves (WRCs) were developed for each soil type using $100 \mathrm{~cm}^{3}$ core samples with three replications. The hanging water column method was used to obtain the relation between volumetric water content $(\theta)$ and matric potentials $(\psi)$ of $0,-10,-30$, -60 and $-100 \mathrm{~cm}$, and the pressure plate extractor method was used for $\psi$ values of $-300,-500$ and $-1000 \mathrm{~cm}$.

\subsection{Derived variables}

Field soils' water conditions were evaluated using the degree of saturation $(s)$ and relative gas diffusivity. Values of $s$ and air-filled porosity $(\varepsilon)$ were calculated as follows:

$$
\begin{aligned}
s & =\frac{\theta}{\theta_{\mathrm{s}}} \\
\varepsilon & =\theta_{\mathrm{s}}-\theta
\end{aligned}
$$

Relative gas diffusivity $\left(D_{P} / D_{0}\right)$ was calculated following a Soil Water Characteristic-Based Gas Diffusivity Model (Moldrup et al., 1996, 2000).

$$
\frac{D_{P}}{D_{0}}=\left(2 \varepsilon_{100}^{3}+0.04 \varepsilon_{100}\right)\left(\frac{\varepsilon}{\varepsilon_{100}}\right)^{2+3 / b}
$$




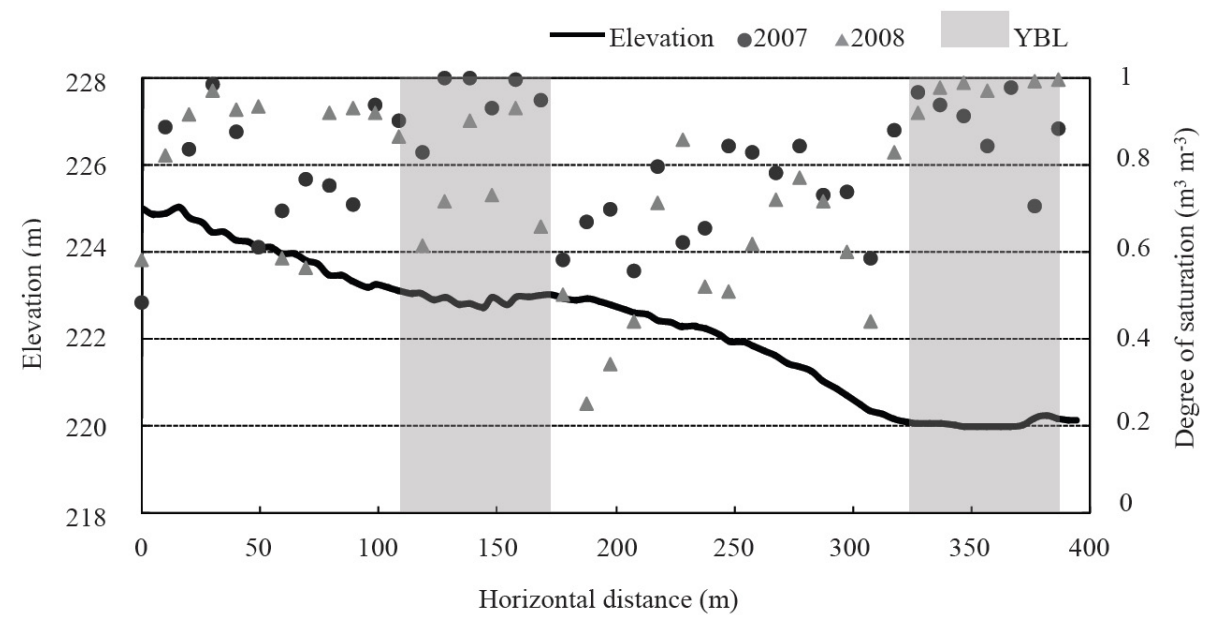

Fig. 2. Elevation, degree of saturation $(s)$ and the stripes of yellowing and browning larch trees (YBL) on the line transect.

where, $D_{P}$ is the gas diffusion coefficient in soil $\left(\mathrm{m}^{2} \mathrm{~s}^{-1}\right)$, $D_{0}$ is the gas diffusion coefficient in free air $\left(\mathrm{m}^{2} \mathrm{~s}^{-1}\right), \varepsilon$ is the soil air-filled porosity $\left(\mathrm{m}^{3} \mathrm{~m}^{-3}\right), \varepsilon_{100}$ corresponds air-filled porosity at $\psi=-100 \mathrm{~cm}$, and $b$ is soil water retention parameter after Campbell (1974). The value $b$ was determined as the slope of the WRC in a log-log coordinate plot.

The differences in $s$ and $D_{P} / D_{0}$ between YBL and NL portions of the transect were compared by Students' $t$ test (1\% level) with a modified and approximated t-value (Snedecor and Cochran, 1967).

Mean annual precipitation in Yakutsk was calculated from 1982-2008 data obtained from the Japanese Meteorological Agency (JMA monthly observation report). To focus on soil water conditions conducive to growing season tree growth, annual cumulative June to the subsequent May precipitation $\left(P_{\mathrm{JM}}\right)$ data was tabulated for the period of June 1982 to May 2008.

\section{Results and discussion}

Horizontal variations in elevation, $s$, and the strips of yellowing and browning larch trees (YBL) on the line transect are shown in Fig. 2. The line transect had gentle slope (0.5 to $\left.2.0^{\circ}\right)$ from North to South. Values of $s$ fluctuated considerably along the transect in both 2007 (0.48 to 1.00$)$, and 2008 (0.24 to 1.00). The YBL regions were located at depressions of the foot slope and showed higher $s$ values. Even though the soil samples were taken at the shallow depth of $0.20 \mathrm{~m}$, several soil samples from YBL were saturated in both years. Soil water content values measured in the present study were high compared to those obtained in previous studies in the same forest. Soil at shallow depths is not normally saturated except in the snowmelt season (Sugimoto et al., 2003; Lopez et al., 2007; Ohta et al., 2008). Mean $s$ values at YBL and NL areas were 0.89 and 0.73 in 2007, and 0.90 and 0.64 in 2008,

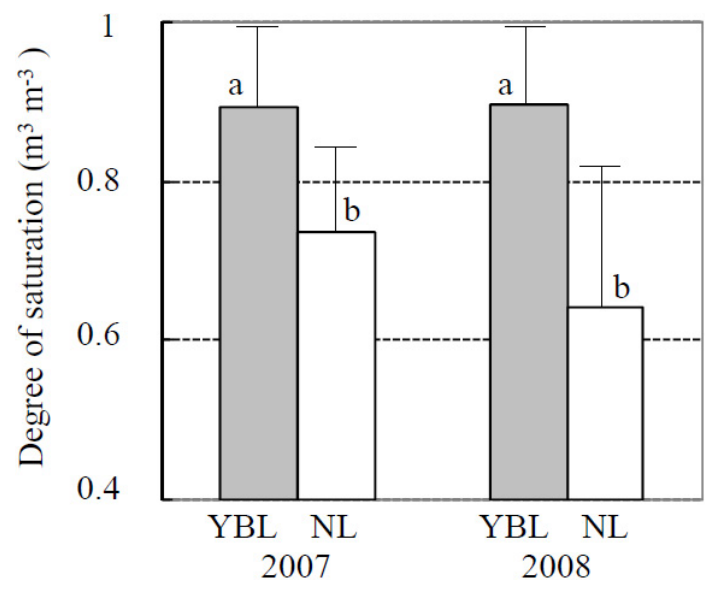

Fig. 3. Mean $s$ values at YBL and NL in 2007 and 2008. Error bars show SDs. Different character shows the significant difference at $P<0.01$.

respectively (Fig. 3). Mean $s$ values at YBL sampling points were significantly higher than those at NL points $(P<0.01)$ in both years.

Under high soil water conditions, root respiration is restricted due to poor soil aeration, and oxygen supply to plant roots decreases (Bergman, 1959). Relative gas diffusivity is often used as a measure to express soil oxygen supply capacity (Grable and Siemer, 1968; Osozawa et al., 1990). Linear relationships were obtained on logarithmically-plotted WRCs for three soil textures (Fig. 4a) and Campbell's soil water retention parameter $b$ was calculated from their slopes. Relative gas diffusivity $D_{P} / D_{0}$, derived from Eq. (3) using $b$ values drawn from the soils' air-filled porosity values (Fig. 4b), shows similar values for loamy sand (LS) and sandy loam (SL). Three soil textures were randomly found on the line transect, there was no clear relation between soil 

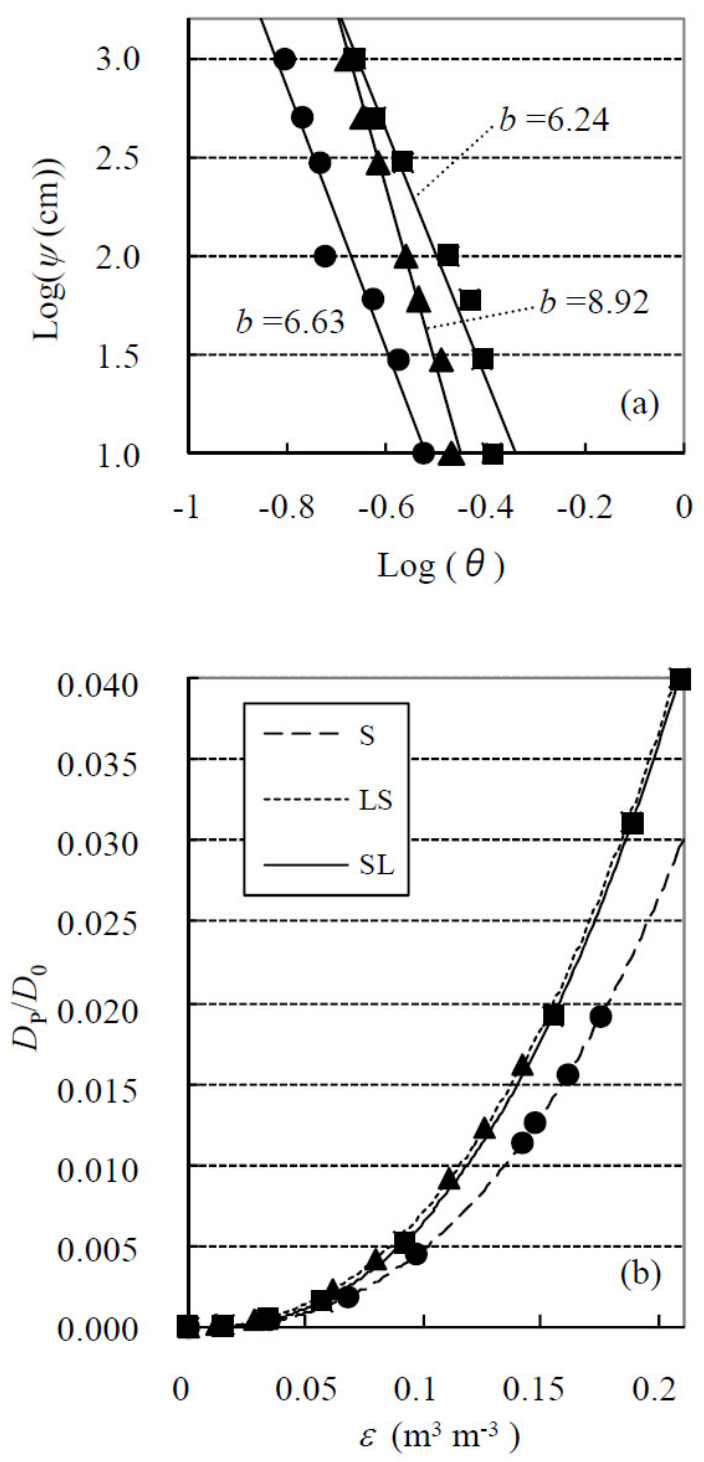

-Sand $\Delta$ Loamy sand $\boldsymbol{\square}$ Sandy loam

Fig. 4. (a) WRCs and Campbell (1974) soil water retention parameter $b$ for each soil texture. (b) Predicted relative gas diffusivity $D_{P} / D_{0}$ as a function of air-filled porosity $\varepsilon$ for each soil texture.

texture and location. The $b$ value is a simple and convenient measure of the pore-size distribution of the soil. The clayey soil generally has high $b$ value. Manyame et al. (2007) showed the $b$ values for sand (S) and LS were 2.0 to 2.8 , Olesen et al. (1999) showed the $b$ value was 2.1 for $\mathrm{S}$ and 3.8 to 5.0 for SL. However, Olesen et al. (2001) reported the $b$ value was 5.1 for S and 3.1 for SL. These results indicate sandy soil has relatively low $b$ value but the most sandy soil dose not always have the lowest $b$ value. Obtained $b$ values in present study (Fig. 4a) were 6.2 to 8.9 which were high compared to those presented in previous studies and SL had lowest $b$ value.

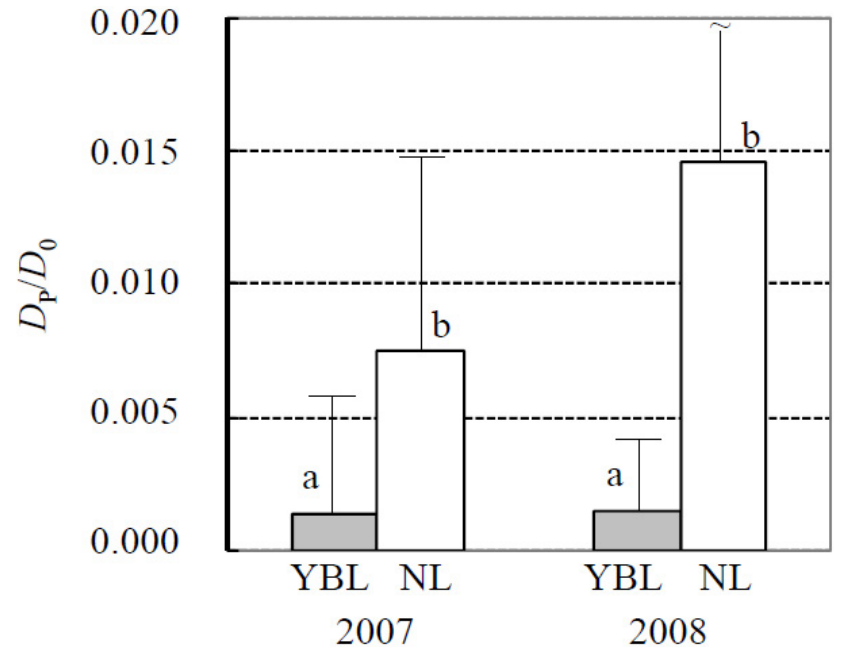

Fig. 5. Mean $D_{P} / D_{0}$ values at YBL and NL in 2007 and 2008. Error bars show SDs. Different character shows the significant difference at $P<0.01$.

Mean $D_{P} / D_{0}$ values at YBL and NL sampling sites were 0.0014 and 0.0075 in 2007, and 0.0015 and 0.0146 in 2008, respectively (Fig. 5). In both years mean $D_{P} / D_{0}$ values for YBL sampling sites were significantly lower than those at NL sites $(P<0.01)$. In both years $D_{P} / D_{0}$ at YBL was lower than the critical value of $D_{P} / D_{0}$ for root respiration of 0.005 proposed by Stepniewski (1981). However, Nishimoto (1982) reported that larch trees are particularly susceptible to oxygen deficiency. The low $D_{P} / D_{0}$ at YBL sampling sites was tied to their elevated soil water content. And their high soil water conditions seemed to have a destructive effect to larch trees, as exemplified by larch trees in YBL zones in 2007 (Fig. 6a) which did not flush in 2008 (Fig. 6b).

Annual precipitation from June to the subsequent next May $\left(P_{\mathrm{JM}}\right)$ at Yakutsk over the period of 1982 to 2008 (Fig. 7) showed a mean value \pm standard deviation of $222 \pm 68 \mathrm{~mm}$. The $P_{\mathrm{JM}}$ values for 2005-2006 and 2006-2007 were $407 \mathrm{~mm}$ and $350 \mathrm{~mm}$, respectively, or 185 and $128 \mathrm{~mm}$ above the 26-year mean, well beyond a standard deviation from the mean. In 2007-2008 the $P_{\mathrm{JM}}$ was only $270 \mathrm{~mm}$, $48 \mathrm{~mm}$ higher than normal, but still within a single standard deviation. The lower transect-wide mean $s$ value in 2008 (0.75) than in $2007(0.80)$, are in accord with to the lesser $P_{\mathrm{JM}}$ in 2007-2008 than 2006-2007; however, mean $s$ values for YBL sampling sites were essentially the same in 2008 (0.89) and 2007 (0.90). This implies that a combination of high precipitation in 2005-2007 and water accumulation in foot slope depressions caused high soil water conditions at YBL in 2007, and the absence of transpiration from dead or damaged trees in YBL zones compounded these high soil water conditions in 2008.

As the frozen layer of the permafrost is largely impermeable (Iwahana et al., 2005), soil water content or soil water 
(a)

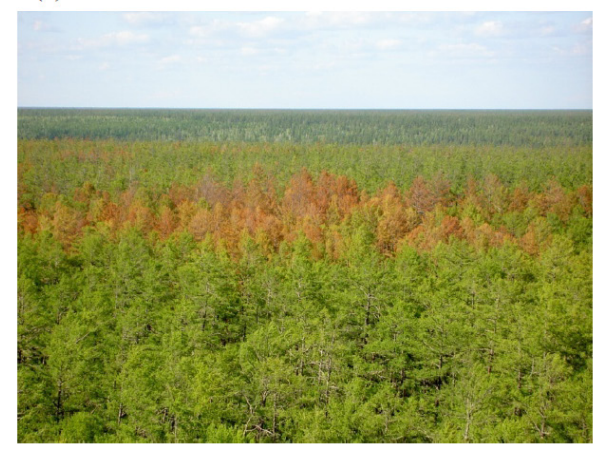

(b)

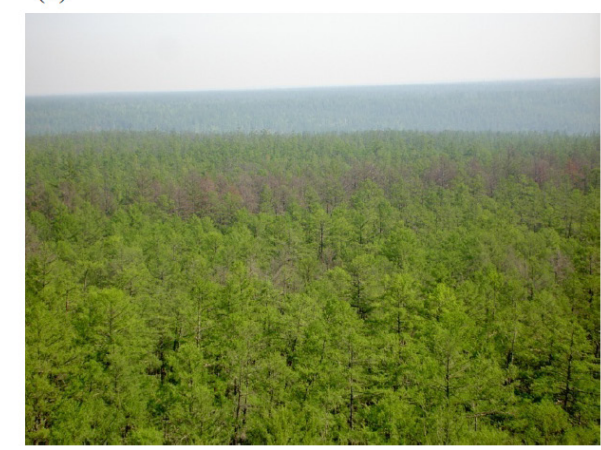

Fig. 6. Tree crown of larch forest in 2007 (a) and in 2008 (b).

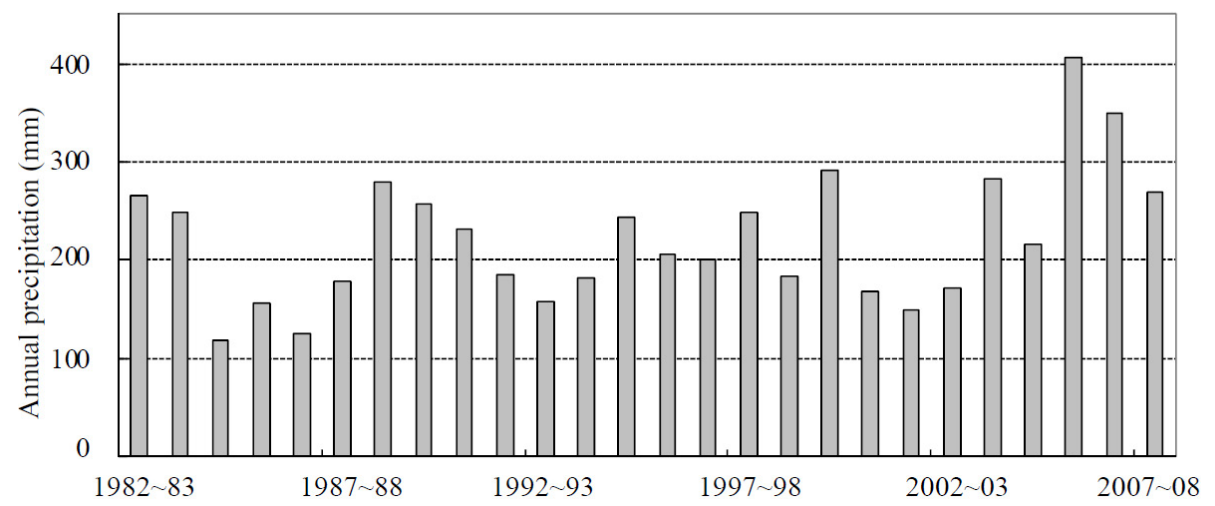

Fig. 7. The amount of annual precipitation from June to the subsequent May $\left(P_{\mathrm{JM}}\right)$ in recent twenty six years in Yakutsk.

stored in the active layer is strongly depended upon the difference between precipitation and evapotranspiration. In normal years, when the forest's growing season evapotranspiration exceeds precipitation (Ohta et al., 2001), larch trees are subjected to a water deficit. Above average $P_{\mathrm{JM}}$ years have occurred frequently in the last twenty six years, but only in 2005-2006 and 2006-2007 have two consecutive years' $P_{\mathrm{JM}}$ exceeded $300 \mathrm{~mm}$ (Fig. 7). Since larch trees in YBL zones began to show leaf yellowing and browning in the 2007 growing season and withered in 2008, the two years' above normal $P_{\mathrm{JM}}$ must have contributed significantly to the die-off of larch trees in the region's foot slope depressions.

The lengths of two stripes of YBL zone were $65 \mathrm{~m}$ and $60 \mathrm{~m}, 125 \mathrm{~m}$ in total, which corresponds to about $31 \%$ of total length of $400 \mathrm{~m}$ transect as shown in Fig. 2. We recognized the larch senescence widely in this forest (Fig. 6), but unfortunately the prevalence of this senescence was not measured. However observed larch senescence in present study might be an early warning sign of forest decline process, which might become more prevalent in the future. To clarify the prevalence of larch senescence in this region, it needs further study conducted over a wide area using GIS or remote sensing.
Emission of $\mathrm{CO}_{2}$ by forest fires encouraged by dry condition in taiga forests has attracted the attention of global warming investigators (Kasischke and Bruhwiler, 2003). While on the positive side, an increase in precipitation might mitigate water stress of larch trees and decrease the number of forest fires, supranormal precipitation for two consecutive years blighted larch trees. Soil water stored in the active layer should significantly increase in subsequent years due to the absence of tree transpiration. In the permafrost region of eastern Siberia, when excess permafrost ice thaws after a severe forest disturbance, the surface depressions forms thermokarst, which is termed "alas" in Siberia (Desyatkin, 1993). Abundant melt water from thawing permafrost flows out and makes pond in depression, causing trees to die (Osterkamp et al., 2000; Jorgensen et al., 2001). Senescence of larch trees due to supranormal precipitation in present study likely occurs through a similar process as that of thermokarsting since both are linked to forest disturbance and both contribute to saturated soil water conditions in the active layer. Forests are generally a sink of greenhouse gases (IPPC, 2001) but can become a source of greenhouse gases upon the senescence of the trees, such as may occur when wet areas are expanded. In addition to $\mathrm{CO}_{2}$ emissions, such decay may generate $\mathrm{CH}_{4}$ emissions under unaerobic 
soil conditions (Goulden et al., 1997; Melillo et al., 2002). The present study demonstrates that taiga forest areas are very sensitive to changes in the precipitation regime.

Global climate change scenarios predict an increase in average global precipitation in the present century and this change will be most pronounced in high latitudes (IPCC, 2001), such as eastern Siberia. The Siberia taiga forest extends widely over permafrost soil. If supernatural precipitation, comparable to the seasons in 2005-2006 and 20062007 occurred repeatedly, this might lead to strong increase of soil water content and result in an increase of greenhouse gas emissions.

\section{Conclusions}

Soil water conditions in an east Siberian larch forest, which showed growing season yellowing and browning of leaves, were evaluated using degree of saturation, $s$ and predicted relative gas diffusivity, $D_{P} / D_{0}$. Mean $s$ values at sampling sites inside zones of yellowing and browning larch trees (YBL) was significantly higher than in areas with normal growth larch trees (NL). Supranormal precipitation in two consecutive years and the low infiltration capacity of frozen permafrost layer led to high soil water conditions at YBL sites. Mean $D_{P} / D_{0}$ values at YBL sites were significantly lower than those measured at NL sites. Low $D_{P} / D_{0}$ at YBL sites caused by elevated soil water content had a negative effect on larch trees rather than mitigating water stress. These results imply that climate change could contribute to spreading forest decline, expanding wet areas in the absence of transpiration from larch trees, and $\mathrm{CH}_{4}$ emissions under unaerobic soil conditions. The taiga forest ecosystem is, therefore, very susceptible to climate changes and may present a danger of accelerating greenhouse gas emissions.

Acknowledgements. This study was funded by Grant-in-Aid for Scientific Research (18255014) of the Japanese Society for the Promotion of Science (JSPS).

Edited by: N. Romano

\section{References}

Archibold, O. W.: Coniferous forest, in: Ecology of world vegetation, Chapman \& Hall, London, 238-279, 1995.

Bergman, F.: Oxygen deficiency as a cause of disease in plant, Bot. Rev., 25, 417-485, 1959.

Brown, J., Ferrians Jr., O. J., Heginbottom, J. A., and Melnikov, E. S.: Circum-Artic map of permafrost and ground-ice conditions, Circum-Pacific Map Series CP-45, U.S. Geological Survey, 1997.

Campbell, G. S.: A simple method for determining unsaturated conductivity from moisture retension data, Soil Sci., 117, 311-314, 1974.

Conard, S. G., Sukhhinin, A. I., Stocks, B. J., Cahoon, D. R., Davidenko, E. P., and Ivanova, G. A.: Determining effects of area burned and fire severity on carbon cycling and emissions in Siberia, Clim. Change, 55, 192-211, 2002.

Desyatkin, R. V.: Syngenetic soil salinization during thermokarst alas formation, Eurasian Soil. Sci., 25, 38-46, 1993.

Epron, D., Farque, L., Lucot, E., and Badot, P. M.: Soil $\mathrm{CO}_{2}$ efflux in a beech forest: the contribution of root respiration, Ann. For. Sci., 56, 289-295, 1999.

Food and Agriculture Organization: Global Forest Resources Assessment 2000. Main report, FAO Forestry Paper No. 124, Rome, 2001.

Goulden, M. L. and Crill, P. M.: Automated measurements of $\mathrm{CO}_{2}$ exchange at the moss surface of a black spruce forest, Tree Physiol., 17, 537-542, 1997.

Grable, A. R. and Siemer, E. G.: Effects of bulk density, aggregate size, and soil water suction on oxygen diffusion, redox potentials, and elongation of corn roots, Soil Sci. Soc. Proc., 32, 180-186, 1968.

IPPC: Climate Change 2001: The Scientific Basis, Contribution of working group 1 to the third assessment report of the intergovernmental panel on climate change, edited by: Houghton, J. T., Ding, Y., Griggs, D. J., Noguer, M., van der Linden, P. J., Dai, X., Maskell, K., and Johnson, C. A., Cambridge University Press, Cambridge, United Kingdom and New York, NY, USA, 2001.

Isaev, A. S., Korovin, G. N., and Bartalev, S. A.: Using remote sensing to assess Russian forest fire carbon emissions, Clim. Change, 55, 235-249, 2002.

Iwahana, G., Machimura, T., Kobayashi, Y., Fedorov, A. N., Konstantinov, Y., and Fukuda, M.: Influence of forest clearcutting on the thermal and hydrogical regime of the active layer near Yakutsk, eastern Siberia, J. Geophys. Res., 110, G02004, doi:10.1029/2005JG000039, 2005.

Jorgenson, M. T., Racine, C. H., Walters, J. C., and Osterkamp, T. E.: Permafrost degradation and ecological changes associated with a warming climate in Central Alaska, Clim. Change, 48, 551-579, 2001.

Kasischke, E. S.: Boreal ecosystems in the global carbon cycle, in: Fire, Climate Change and Carbon Cycling in the Boreal Forest, edited by: Kasisschke, E. S. and Stocks, B. J., Ecological Studies 138, Springer-Verlag, New York, 19-30, 2000.

Kasischke, E. S. and Bruhwiler, L. P.: Emissions of carbon dioxide, carbon monoxide, and methane from boreal forest fires in 1998, J. Geophys. Res., 108, 8146, doi:10.1029/2001JD000461, 2003.

Kuwada, T., Kotake, T., Takeuchi, S., Maximov, T. C., and Yoshikawa, K.: Relationships among water dynamics, soil moisture and vapor pressure deflect in a Larix gmelinii stand, eastern boreal Siberia, J. Jpn. For. Soc., 84, 246-254, 2002.

Lopez, C. M. L., Saito, H., Kobayashi, Y., Shirota, T., Iwahana, G., Maximov, T. C., and Fukuda, M.: Intreannual environmental-soil thawing rate variation and its control on transpiration from Larix cajanderi, central Yakutia, eastern Siberia, J. Hydrol., 338, 251260, 2007.

Manyame, C., Morgan, C. L., Heliman, J. L., Fatondji, D., Gerard, B., and Payne, W. A.: Modeling hydraulic properties of sandy soils of Niger using pedotransfer functions, Geoderma, 141, 407-415, 2007.

Melillo, J. M., Steudler, P. A., Aber, J. D., Newkirk, K., Lux, H., Bowles, F. P., Catricala, C., Magill, A., Ahrens, T., and Morrisseau, S.: Soil warming and carbon-cycle feedbacks to the climate system, Science, 298, 2173-2176, 2002. 
Moldrup, P., Kruse, C. W., Rolston, D. E., and Yamaguchi, T.: Modeling diffusion and reaction in soils: V. Predicting gas diffusivity from the Campbell soil-water retension model, Soil Sci., 161, 366-375, 1996.

Moldrup, P., Olesen, T., Schjønning, P., Yamaguchi, T., and Rolston, D. E.: Predicting gas diffusion coefficient in undisturbed soil from soil water characteristics, Soil Sci. Soc. Am. J., 64, 94$100,2000$.

Nikolaev, A. N., Fedorov, P. P., and Desyatkin, A. R.: Influence of climate and soil hydrothermal regime on radial growth of Larix cajanderi and Pinus sylvestris in central Yakutia, Russia, Scand. J. For. Res., 24, 217-226, 2009.

Nishimoto, T.: Influence of different soil oxygen-supply capasities and compactness levels on the growth of Larix letolepis GORD. and Picea glehnii MAST. Seedlings, J. Jap. For. Soc., 64, 476485, 1982.

Ohta, T., Hiyama, T., Tanaka, H., Kuwada, T., Maximov, T. C., Ohata, T., and Fukushima, Y.: Seasonal variation in the energy and water exchanges above and below a larch forest in eastern Siberia, Hydrol. Processes, 15, 1459-1476, 2001.

Ohta, T., Maximov, T. C., Dolman, A. J., Nakai, T., van der Molen, M. K., Kononov, A. V., Maximov, A. P., Hiyama, T., Iijima, Y., Moors, E. J., Tanaka, H., Toba, T., and Yabuki, H.: Interannual variation of water balance and summer evapotranspiration in an eastern Siberian larch forest over a 7-year period (1998-2006), Agric. Forest Meteorol., 140, 1941-1953, 2008.

Olesen, T., Morldrup, P., and Gamst, J.: Solute diffusion and adsorption in six soils along a soil texture gradient, Soil Sci. Soc. Am. J., 63, 519-524, 1999.

Olesen, T., Morldrup, P., Yamaguchi, T., and Rolston, D. E.: Constant slope impedance factor model for predicting the solute diffusion coefficient in unsaturated soil, Soil Sci., 166, 89-96, 2001.
Osozawa, S., Kozai, S., and Kubota, T.: Evaluationg physical condition of kumamoto soil based on the "Non-Limitting Water Range" concept, Soil Phys. Cond. Plant Growth Jpn., 60, 6-14, 1990.

Osterkamp, T. E., Viereck, L., Shur, Y., Jorgensen, M. T., Racine, C., Doyle, A., and Boone, R. D.: Observations of thermokarst and its impact on boreal forests in Alaska, USA, Arctic Antarctic and Alpine Res., 32, 303-315, 2000.

Shvidenko, A. and Nilsson, S.: Expanding forests but declining mature coniferous forests in Russia, WP-96-59, Intrenational Institute for Applied System Analysis, Laxenburg, 1996.

Snedecor, G. W. and Cochran, W. G.: Statistical Methods, 6th ed., Ames, Iowa State University Press, 1967.

Soja, A. J., Sukhinin, A. I., Cahoon Jr., D. R., Shugart, H. H., and Stackhouse Jr., P. W.: AVHRR-derived fire frequency, distribution and area burned in Siberia, Int. J. Remote Sensing, 25, 19391960, 2004.

Sugimoto, A., Naito, D., Yanagisawa, N., Ichiyaanagi, K., Kurita, N., Kubota, J., Kotake, T., Ohata, T., Maximov, T. C., and Fedorov, A. N.: Characteristics of soil moisture in permafrost observed in East Siberian taiga with stable isotopes of water, Hydrol. Processes, 17, 1073-1092, 2003.

Stepniewski, W.: Oxygen diffusion and strength as related to soil compaction. U. Oxygen diffusion coefficient, Pol. J. Soil Sci., 14, 3-13, 1981.

Takahashi, K., Isaev, A. P., Maximov, T. C., and Saito, H.: Fire history of mature larch forests near Yakutsk, eastern Siberia. In: Proceedings of the 10th Symposium on the Joint Siberian Permafrost Studies between Japan and Russia in 2001, edited by: Fukuda, M. and Saito, H., Sapporo, 65-68, 2002. 